\title{
COMMUNICATION STRATEGIES USED BY PHYSICAL EDUCATION TEACHERS AND COACHES IN RESIDENTIAL SCHOOLS FOR THE DEAF IN THE U.S.
}

\author{
Petra Kurková ${ }^{1}$, Nanci A. Scheetz ${ }^{2}$ \\ ${ }^{I}$ Department of Anthropology and Health Education, Faculty of Education, Palacký University Olomouc, \\ Czech republic \\ ${ }^{2}$ Valdosta State University (GA), Department of Middle, Secondary, Deaf Education
}

\begin{abstract}
Summary: The purpose of this study was to determine what communication and instructional techniques including coaching strategies were being implemented by coaches and physical education (PE) teachers working in residential or day schools for the deaf throughout the U. S. Further, to share this information with coaches and PE teachers in general education classrooms. Questionnaire was answered electronically from 32 coaches and PE teachers ( $38 \%$ return rate). Topics in the survey included: a) types of sports/PE classes; b) mode of communication used; c) coaching and teaching techniques; d) coaching and teaching strategies; e) breakdowns in communication; f) advice to new coaches a teachers starting out in the field. Advice for new coaches, who had not previously worked with the individuals who are deaf or hard of hearing $(\mathrm{D} / \mathrm{HH})$, six themes emerged: become fluent in ASL, remember to get the student's attention before you start signing, use a lot of modelling, role playing, and videos (when needed), keep it simple, stress the fundamentals and insist on repetition until skills are mastered, and be flexible, each player will learn differently. Our results suggest that targeted and adapted communication strategies in PE and physical activities play important role for individuals who are $\mathrm{D} / \mathrm{HH}$.
\end{abstract}

Keywords: physical activity, sport settings, deaf, hard of hearing

DOI 10.1515/afepuc-2016-0001

(C) Acta Facultatis Educationis Physicae Universitatis Comenianae 


\section{Introduction}

The American population is a macrocosm of diversity. Comprised of individuals from different ethnic, cultural, and socioeconomic backgrounds, the majority of them have one trait in common: they can all hear. Representing a hearing world, these individuals value their ability to hear and speak, and their ease at communicating with each other. For the majority, the thought of losing their hearing and not having access to music, radio broadcasts, movies, and announcers at sporting events, is devastating. It is inconceivable how anyone could go through life without hearing.

However, within this majority hearing society, a cultural, linguistic, minority group resides that is comprised of Deaf individuals. Characterized by individuals with varying degrees of hearing loss, from all walks of life, ethnic backgrounds, and socio economic status these Deaf individuals embrace American Sign Language (ASL) as their language, and cherish a number of shared cultural beliefs that all of the members value. Contrary to the majority of the society, these individuals do not perceive their hearing loss as a disability, but rather as part of their unique identity. Culturally Deaf individuals, designated by a capital "D" in the literature, actively seek out others who hold similar beliefs (Stewart 1991). Thus, membership in Deaf culture is not determined by degree of hearing loss in so much as one's attitude toward what it means to be deaf (in this case the lower case "d" is used to indicate a medical condition).

It is well documented in the literature that Deaf persons who embrace ASL and Deaf values have a different language and a different culture (Ammons 1990; Stewart 1991). Their hearing loss may not be obvious to hearing individuals when they first encounter them, but both the Deaf and the hearing person typically experience major difficulties when they attempt to communicate. It is the only "disability" that hearing people can be as disabled as those who are Deaf. One can assist a blind person when crossing the street, or offer to push a wheelchair uphill. However, if the hearing individual does not know ASL, he or she is as disabled as the Deaf individual who does not use speech to communicate. The communication breakdown occurs because both individuals lack a specific skill set.

One of the unifying themes of Deaf culture is Deaf sport. Originating in residential schools for the deaf during the 1800 s, students attending these programs actively competed against athletes from other residential schools in a variety of sports. These lively competitions between schools continue today with students participating on football, basketball, and soccer 
teams, to name just a few. From these early origins of organized competition, the love of sport within the Deaf community has evolved. Regardless of whether the sporting event is held on a local, state, or national level or rises to an international level, such as Deaflympics, the excitement and support each event generates from within the Deaf community is tremendous (Ammons 2009) and also has positive effects on all aspects on their life (Nemček 2014; Nemček and Kručanica 2014).

Until the mid 1970s, the majority of students who were deaf or hard of hearing were educated in residential schools or day schools for the deaf. Within these institutions sports flourished, and the love of competing against teams from rival residential schools was and still is cherished. However, with the advent of the Education for All Handicapped Children Act in 1975, Public Law 94-142 the demographics of deaf education was significantly altered. This legislation, referred to as the Mainstreaming Law, mandated that schools provide a free and appropriate public education for children with disabilities between the ages of 5 and 18 . This paved the way for children who were deaf to attend their neighborhood schools. As a result, today, approximately $51.9 \%$ of students with varying degrees of hearing loss are receiving the majority of their education in regular education settings (National Center for Education Statistics 2009).

What impact did it have on Deaf sport? Do students who are deaf engage in the same amount of physical activity in these educational settings compared to those attending residential programs? In recent years, several studies have been conducted that have dealt with the environment and conditions in which students with hearing loss are educated in general schools, particularly in PE classes (Anderson 2015; Ciolca and Mogaldea 2013; Cerney 2007; Lieberman et al. 2007; Luckner and Muir 2001).

Various researches have indicated that children who are deaf or hard of hearing may engage in a lower level of physical activity and fitness than their hearing peers (Ellis et al. 2014; Jansma and French 1994; Dair et al. 2006). This fact may be caused by various environmental factors rather than specific physiological factors related to their deafness (Dummer et al. 1996). Additional research conducted by Butterfield et al. (1993), revealed that the specific type of school, curricular focus, the role of parents, opportunities for training and games significantly affect motoric development and thus the physical activity of persons with evidence of hearing loss.

Lieberman et al. (2000) studied the mutual interaction between hearing pupils and pupils with hearing loss during PE classes. They wanted to determine whether and how the mutual interaction affected the increase in the physical performance, if any, in pupils that 
were deaf or hard of hearing. The results indicated that in PE classes that included pupils with varying degrees of hearing loss, such interaction helped to increase all of the students' motivation as well as their level of physical performance.

Kurková (2009) described the fears felt by pupils with hearing loss regarding misunderstandings in communication, delayed reactions when beginning a new activity and the fears surrounding the potential for breaking hearing aids when participating in contact sports in PE classes. Negative emotional responses appeared in relation to feelings such as anxiety and stress. Due to their loss of hearing and related communication barriers, students who are deaf or hard of hearing may be limited in their access to experiences that subsequently affect their social, educational, professional, recreational and psychosocial development (Sims et al. 1982). Deaf individuals who attend schools for the deaf prefer racing with other athletes who are Deaf than competing with or against hearing athletes (Kurková et al. 2010). Participating in sports for the deaf also has, for such athletes, a cultural significance since they share a language (sign language), cultural values and similar attitudes towards their deafness (Ellis et al. 2014; Stewart et al. 1988). Even though there is research to support the fact that hearing coaches are of great help in shaping the performance of athletes with varying degrees of hearing loss, the athletes themselves confided that they felt lonely and ignored when in the environment of a general club among their hearing peers and trainers (Stewart et al. 1991).

This point of view was also largely supported in a study by Kurková et al. (2011) in which they verified that athletes who have a hearing loss prefer separate competitions. It was discovered that such athletes find it important to enjoy the opportunity of socializing during sporting events for the deaf, which is possible since they share the same cultural values and the same language. Similar preferences for separate sports contests by athletes with varying degrees of hearing loss have also been mentioned in various other studies (Stewart et al. 2001; Stewart and Ellis 1999). This means that such athletes are not limited as a consequence of their loss of hearing (unless their vestibular system was impaired), and they can choose whether to compete with hearing athletes or only with other athletes who are deaf or hard of hearing. Lieberman et al. (2000) have studied the importance of mutual cooperation and communication between students with hearing loss and their hearing peers. Their results indicated that classmates who have been trained with respect to the communication needs of students who are deaf or hard of hearing significantly support the inclusion of such students in physical education and other physical activities. 
Nevertheless, a particular preference for a specific mode communication is related to the degree of hearing loss and its diagnosis, to the quality of rehabilitation, the type of educational institution and the sociocultural environment in which the child with a hearing loss is brought up. In addition to those aspects, the timely diagnosis of the loss of hearing, early care, the ability to use hearing aids and cochlear implants or other technological aids facilitating communication also play a significant role in successfully managing their communication (Ellis et al. 2014; Scheetz 2004; Strnadová 2001).

The purpose of this study was to determine what communication/instructional techniques and coaching strategies were being implemented by coaches and PE teachers teaching/coaching in residential/day schools for the deaf throughout the United States, with the intent of sharing this information with coaches/PE teachers in general education classrooms.

\section{Methods}

\section{Participants and data collection}

In order to ascertain which communication/instructional techniques and coaching strategies were being implemented the researchers decided they would solicit feedback from physical education teachers and coaches at schools for the deaf in the United States. They began with a review of the literature to determine what types of information had been previously gathered. A review was conducted from 2014 back until 2000. The search did not reveal any questionnaires. However, a conversation with a colleague indicated a doctoral student had developed a survey with related questions while working on his dissertation. The dissertation was obtained and later the questions used in the pilot survey were compared to those found in the dissertation to make sure the questionnaire was comprehensive (Rochon et al. 2006).

It was decided that a questionnaire would be devised and sent electronically to all of the resident and day schools for the deaf in the U.S. A questionnaire, in the form of a brief survey, was developed and sent to three physical education/coaches for feedback. Based on the feedback that was, received modifications were made to the survey and it was then sent to the Department of Physical Education and Kinesiology at one of the researcher's universities for additional feedback from professors specializing in the field of physical education. Once the survey was finalized, it was formatted in Qualtrics. 
The relevant Ethics Committee approved the research design. All of the participants were informed about purpose of this study prior to data collection and informed they could withdraw from the survey at any point time in while completing it. A data base was compiled from the list of Schools for the Deaf published by Gallaudet University. This list included both residential and day schools throughout the U.S. The list was comprised of 84 schools for the deaf. Each of the 84 schools received a copy of the survey. The cover letter was addressed to coaches and PE teachers stating that the goal of the research project was to investigate how coaches and PE teachers communicate with Deaf athletes/players; the letter further indicated that participants could withdraw at any time during the process. The survey consisted of 13 questions with 7 questions designed as multiple-choice questions with 3 of the questions providing an opportunity to add additional information. In addition, 6 of the questions were designed as open-ended questions.

\section{Data analysis}

The data were described in relative and absolute frequencies. Topics covered in the survey included: a) types of sports/PE classes that were offered and that the individual completing the survey taught/coached; b) mode of communication used; c) coaching/teaching techniques that were implemented; d) coaching/teaching strategies that were incorporated; e) how breakdowns in communication occurred; f) advise to new coaches/teachers starting out in the field.

\section{Results}

Of the 84 schools that were contacted, 32 individuals responded constituting a $38 \%$ return rate. States represented in the survey included 1 from the North, 2 from the West, 2 from the Northeast, 12 from the Mid-Atlantic States, and 6 from the Southeast. Thirty per cent of those responding taught/coached at day schools, while $70 \%$ worked within residential settings. Fourteen or $50 \%$ of the individuals responding indicated they were PE teachers, while 21 of those responding or $75 \%$ indicated they were coaches. Among those responding, $29 \%$ indicated they had 0 to 5 years' experience teaching/coaching; $11 \%$ reported that they had 6 to 10 years of experience, $14 \%$ stated they have 11 to 15 years' experience, and $43 \%$ indicated that they had 16 or more years of experience. The PE teachers/coaches reported varying levels of proficiency in ASL, with $29 \%$ indicating they possessed native or near native skills in ASL, $57 \%$ indicated they were proficient, $4 \%$ stated they were adequate, 
while 4\% said their ASL skills were developing. Seven per cent of those responding indicated that the question regarding ASL proficiency did not apply to them. These individuals indicated that worked at schools with an oral philosophy and did not use ASL on a general basis.

Within the survey, participants were asked to indicate which sports they currently taught or coached. Lists of multiple-choice options were available with an option to list other sports as needed. The 5 most frequently taught/coached sports included: basketball, soccer, and volleyball, and football (Table 1).

Table 1

Representation of sports currently taught or coached

\begin{tabular}{|l|l|l|}
\hline Sports & Total score & $\mathbf{\%}$ \\
\hline Baseball & 4 & 15 \\
\hline Basketball & 18 & 69 \\
\hline Cheerleading & 2 & 8 \\
\hline Football & 9 & 35 \\
\hline Field Hockey & 5 & 19 \\
\hline Lacrosse & 2 & 8 \\
\hline Soccer & 11 & 42 \\
\hline Softball & 5 & 19 \\
\hline Swimming & 4 & 15 \\
\hline Tennis & 4 & 15 \\
\hline Track and field & 8 & 31 \\
\hline Volleyball & 11 & 42 \\
\hline Other sports: please list & 9 & 35 \\
\hline
\end{tabular}

Participants were also asked to check what mode or modes of communication they used to communicate with Deaf athletes during practice and/or students in their classes. Again, lists of multiple-choice options were available to list other modes of communication utilized. While $96 \%$ of the respondents indicated they used ASL to communicate, the second highest response was Manual Communication with $22 \%$ (Table 2).

Table 2

Communication mode used to communicate with Deaf athletes

\begin{tabular}{|l|c|c|}
\hline Communication mode & Total score & $\mathbf{\%}$ \\
\hline American Sign Language (ASL) & 26 & 96 \\
\hline Manual Communication & 6 & 22 \\
\hline Signed English & 5 & 19 \\
\hline Signing Exact English (SEE) & -- & -- \\
\hline Contact Signing (Pidgin Signed English) & 3 & 11 \\
\hline
\end{tabular}




\begin{tabular}{|l|c|l|}
\hline Sign Supported Speech & 4 & 15 \\
\hline Cued Speech & -- & -- \\
\hline Invented signs or use of conventional signs for particular sports & 2 & 7 \\
\hline Oral communication & 8 & 30 \\
\hline Written communication & 3 & 11 \\
\hline Other & 3 & 11 \\
\hline
\end{tabular}

In addition to discovering which mode or modes of communication coaches/PE teachers relied on for communication, the researchers were also interested in finding out what techniques were utilized to teach new plays or skills. Respondents indicated that they modeled the skills for the players $96 \%$ of the time; $78 \%$ of those participating in the survey indicated that the play or skill was re-taught by other students/team members, and $74 \%$ indicated they used white boards to teach new plays or skills (Table 3).

Table 3

Techniques used to teach new plays or skills

\begin{tabular}{|l|c|c|}
\hline Used teaching techniques & Total score & $\mathbf{\%}$ \\
\hline Visual Aids & & \\
\hline Pictures & 11 & 41 \\
\hline White boards & 20 & 74 \\
\hline Technology & & \\
\hline Smart board & 11 & 41 \\
\hline Videos with open or closed captions & 12 & 44 \\
\hline You Tube demonstrations & 11 & 41 \\
\hline iPad videos & 6 & 22 \\
\hline Other forms of technology & 5 & 19 \\
\hline Modeling the skill for the players & 26 & 96 \\
\hline Re-teaching by other students/team members & 21 & 78 \\
\hline Other techniques that you use & 6 & 22 \\
\hline
\end{tabular}

Although this survey represents only a small number of individuals there are some trends reported among those that responded. First, it is interesting to note that although there is evidence to support the current use of technology, these coaches still primarily relied on modeling, re-teaching by other team members, and the use of white boards to teach new plays or skills.

One of the other purposes of the survey was to determine what the causes were for breakdowns in communication between teachers/coaches and their students/athlete. While 52 $\%$ indicated that the student/athlete was not attending when the message was delivered, $52 \%$ also indicated that the student/athlete misinterpreted the content. Thirty-six per cent of the 
respondents indicated that the content of the message was not presently clearly or accurately, $32 \%$ indicated the student/athlete misinterpreted the intent of the message, while $12 \%$ stated that the message was not appropriately transmitted. Twenty-four per cent indicated that there were other reasons that breakdowns occurred in communication (Table 4).

When the coaches/PE teachers were asked to provide advice for new coaches, who had not previously worked with the Deaf/hard of hearing population, six themes emerged. They included: become fluent in ASL, remember to get the student's attention before you start signing, use a lot of modelling, role playing, and videos (when needed), keep it simple, stress the fundamentals and insist on repetition until skills are mastered, and be flexible, each player will learn differently.

Table 4

Causes of breakdown in communication

\begin{tabular}{|l|c|c|}
\hline Causes of breakdown in communication & $\begin{array}{c}\text { Total } \\
\text { score }\end{array}$ & $\mathbf{\%}$ \\
\hline $\begin{array}{l}\text { Content of the massage was not presented clearly or } \\
\text { accurately }\end{array}$ & 9 & 36 \\
\hline The message was not appropriately transmitted & 3 & 12 \\
\hline $\begin{array}{l}\text { The student/athlete was not attending when the } \\
\text { message was delivered }\end{array}$ & 13 & 52 \\
\hline The student/athlete misinterpreted the content & 13 & 52 \\
\hline $\begin{array}{l}\text { The student/athlete misinterpreted the intent of the } \\
\text { message }\end{array}$ & 8 & 32 \\
\hline
\end{tabular}

\section{Discussion}

Recognizing that historically Deaf sport has been, and continues to be, a valued tradition within residential schools, the authors of this research wanted to determine how coaches and physical education teachers, in these environments, communicate with their Deaf and hard of hearing players. The goal was to capture communication/instructional techniques, and coaching strategies so they could be shared with PE teachers and coaches employed in general education classrooms. By sharing this information, coaches would have an increased awareness of the strategies and techniques that have been found to be beneficial among this population of PE teachers/coaches that responded, when working with athletes who are deaf and hard of hearing. Thus, if these strategies were implemented athletes who are deaf and hard of hearing would eventually benefit from these coaching strategies. 
In the present study, the participants answered that most frequently taught/coached sports included basketball, soccer, volleyball, and football. Similar collective sports were also determined in the Slovak study (Kurková et al. 2015), which was concerned besides other things on preference in PE classes in pupils who are deaf or hard of hearing. Those pupils preferred swimming and then floorball, soccer and basketball. Themes recurring in the open ended questions indicated that teaching team skills can be challenging, in particular conveying the concept of what each individual's role is while out on the court or on the field. Additionally, conveying communication during a game, providing students with techniques to memorize plays, and conveying competition rules were also noted. Respondents provided numerous responses when asked how they secured the attention of their players and communicated with them during a game against other team members from schools for the deaf.

Successfully-managed communication within a class (between a student with a hearing loss, a teacher and their classmates) may play a role in the students' ability to feel like they are a part of the class collective, and not experience any limits when participating in general PE. However, one needs to take into account the fact that hearing loss can place high demands on their attention. Unlike their hearing counterparts who can listen auditorily while they engage in physical activity in general educational/training settings, those who cannot hear must first listen with their eyes before they can actively participate. Relying on speech reading, or the services of a sign language interpreter, the demands placed on the individual can be taxing at times. Furthermore, depending on the degree and frequency level of the hearing loss, students with residual hearing are oftentimes challenged to determine when the coach is conveying information and when students are cheering from the side-lines. This can present additional difficulties for a student who utilizes a hearing aid to enhance their ability to hear. They may find it is difficult to distinguish a distant teacher's voice or instructions from a coach versus the shouting and cheering next to them (Best et al. 2002).

Coaches repeatedly mentioned waving a towel or waving their arms to get players' attention, using hand waving or intermediaries, flags or gestures, or using an FM system that would synchronize to their players' hearing aids. Frequently, it was noted that impressing upon players to look frequently in the coach's direction was imperative so plays could be conveyed. One final comment that was repeated was to "sign the name and wave/point in the direction of the target player." In that way the other players would inform the target player that the coach wanted them. Several coaches also indicated that "hollering" at players does not work well because it draws some unwanted attention and distracts players. These finding 
were in accordance with recommendations of other studies (Reich et al. 2009; Schultz et al. 2013). Also, in a study of Zaccagnini (2005) who focused to conditions in PE classes of students with hearing loss (in general schools and in schools specifically established for students who were deaf and hard of hearing), was recommended that PE teachers need to master the following professional competences: a) they must have adequate subject fieldrelated knowledge and $b$ ) they must be thoroughly trained regarding the specifics that need to be taken into consideration with regard to the educational process of students with a disability.

One of the primary limitations of the study was the $38 \%$ return rate. Although the responses do provide a snapshot of how coaches/teachers are communicating with their players/students across the nation, it by no means is comprehensive, or necessarily indicative of communication modes or techniques used by the majority of all individuals involved in this profession. However, it does provide some insights into effective communication strategies and techniques that can be used when working with this population.

\section{Conclusion}

Regardless of whether students who are deaf or hard of hearing are enrolled in a general school or attend a school for the deaf, comprehensive communication is a necessary precondition for successfully managing their academic requirements and fully integrating them into the class collective. A targeted support of communication and mutual collaboration within the class or school may alleviate or eliminate any possible feelings of social exclusion among those who are deaf or hard of hearing. On the contrary, an example of an inappropriate approach taken by a teacher at a general school is a situation where the teacher verbally explains everything in great detail to the hearing students, but very often provides only rather simple instructions to pupils with a significant degree of hearing loss, or who relies primarily on gestures when communicating with them (Anderson, 2015; Ciolca and Mogaldea 2013; Stewart and Kluwin 2001). Drawbacks in communication may, for students with varying degrees of hearing loss, can result in insufficient development their verbal or sign vocabulary. Consequently, oftentimes they are not afforded enough opportunities during the school day to engage in social interaction, and through it, develop their spoken (or sign) language.

With the advent of IDEA (Individuals with Disabilities Education Act 2004) student populations in residential schools began to decline creating a shift in the demographics of where and how student who are deaf and hard of hearing are being educated. With the influx of this population being included in general education programs the need for PE teachers and 
coaches to develop a cultural awareness of what it means to be deaf is critical. Becoming familiar with teaching/coaching techniques and communication strategies affords players who are deaf and hard of hearing have greater opportunities to participate in intermural and competitive team sports. In order to insure that schools are providing students with a free and public education in the least restrictive environment it is imperative that all students be afforded the opportunity to participate in extra-curricular events. This includes accommodating students who are deaf and hard of hearing that want to try out, and, if selected, participate in team sports. By developing an awareness and sensitivity to the unique needs of this cultural/linguistic population full access can be granted benefitting both the students who are deaf and hard of hearing as well as the hearing coaches and players.

\section{References}

1. AMMONS, D.K., 1990. Unique identity of the World Games for the Deaf. Palaestra, 6, 40-43.

2. AMMONS, D.K., 2009. The International Committee on Sports for the Deaf and the Deaflympics. In: MOORES D and M. MILLER (Eds.) Deaf people around the World: Educational and social perspectives (pp. 373-386). Washington, DC: Gallaudet University Press. ISBN 9781563684104.

3. ANDERSON, K.L., 2015. Access is the issue, not hearing loss: new policy clarification requires schools to ensure effective communication access. Perspectives on Hearing and Hearing Disorders in Childhood. American Speech-Language-Hearing Association, 25, 24-36.

4. BEST, C., L. LIEBERMAN and K. ARNDT, 2002. Effective use of interpreters in general physical education. Journal of Physical Education, Recreation and Dance, 73, 45-50.

5. BUTTERFIELD, S.A., H. VAN DER MARS and J. CHASE, 1993. Fundamental motor skill performances of deaf and hearing children ages 3 to 8. Clinical Kinesiology, 47, 2-6.

6. CERNEY, J., 2007. Deaf education in America: Voices of children from inclusion settings. Washington, DC: Gallaudet University. ISBN 9781563683626.

7. CIOLCA, C. and C. MOGALDEA, 2013. Types of communication in kinetotherapy classes involving students with hearing impairments. Procedia Social and Behavioral Sciences, 117, 610-615.

8. DAIR, J., K. ELLIS and L.J. LIEBERMAN, 2006. Prevalence of overweight among deaf children. American Annals of the Deaf, 151, 318-326. 
9. DUMMER, G.M., J.L. HAUBENSTRICKER and D.A. STEWART, 1996. Motor skill performances of children who are Deaf. Adapted Physical Activity Quarterly, 13, 400-414.

10. Education for All Handicapped Children Act in 1975, Public Law 94-142.

11. Individuals with Disabilities Education Improvement Act of 2004, Pub. L. No. 108-446 Stat. 2647 (2004).

12. ELLIS, M.K., L.J. LIEBERMAN and G.M. DUMMER, 2014. Parent influences on physical activity participation and physical fitness of deaf children. Journal of Deaf Studies and Deaf Education, 19(2), 270-281.

13. JANSMA, P. and R. FRENCH, 1994. Special Physical Education. Englewood Cliffs, NJ: Prentice Hall.

14. KURKOVÁ, P., 2009. Dimenze emočních reakcí v tělesné výchově u žáků se sluchovým postižením v prostředí běžné školy [Dimensions of emotional reactions in physical education by pupils who are deaf or hard of hearing in general schools settings]. Česká kinantropologie [Czech Kinanthropology], 13, 40-49.

15. KURKOVÁ, P., D. NEMČEK and J. LABUDOVÁ, 2015. Pupils with sensory disabilities in Physical Education lessons: Attitudes and preferences. Acta Gymnica, 45, 139-145.

16. KURKOVÁ, P., N.A. SCHEETZ et J. STELZER, 2010. Health and physical education as an important part of school curricula: A comparison of schools for the deaf in the Czech Republic and the United States. American Annals of the Deaf, 155, 78-95.

17. KURKOVÁ, P., H. VÁLKOVÁ and N.A. SCHEETZ, 2011. Factors impacting participation of European elite deaf athletes in sport. Journal of Sports Sciences, 29, 607618.

18. LIEBERMAN, L.J., K. ARNDT and S. DAGGETT, 2007. Promoting leadership in physical education and recreation. Journal of Physical Education, Recreation et Dance, $78,46-50$.

19. LIEBERMAN, L.J., J.M. DUNN, H. VAN DER MARS and J. MC CUBBIN, 2000. Peer tutors' effects on activity levels of deaf students in inclusive elementary physical education. Adapted Physical Activity Quarterly, 17, 20-39.

20. LUCKNER, J.L. and S. MUIR, 2001. Successful students who are deaf in general education settings. American Annals of the Deaf, 146, 435-446.

21. National Center for Education Statistics, 2009. Digest of educational statistics. Retrieved from http://nces.ed.gov/pubsearch/pubsinfo.asp?pubid=2010013.

22. NEMČEK, D., 2014. Spokojnost' so sociálnymi vzt’ahmi a prostredím ako súčast' kvality života l'udí so sluchovým postihnutím z pohl'adu športovania vo vol'nom čase. 
[Satisfaction with Social Relations and Environment as Parts of the Life Quality of People who are Deaf or Hard of Hearing from the Point of View of Leisure Sports]. In: KRAJČOVIČOVÁ Z. et al. (Eds.), Pohyb a zdravie XI: Pohybová aktivita a zdravý životný štýl - Šport a športový tréning (pp.110-116). [Movement and Health XI: Physical Activity and Healthy Life Style - Sports and Sport Training]. Trenčín, Slovakia: Trenčianska Univerzita A. Dubčeka.

23. NEMČEK, D. and L. KRUČANICA, 2014. Satisfaction with health status in people with hearing impairments. In SCHICKHOFER P.and BUZGÓ G. (Eds.), International Scientific Conference Sports, Physical Activity and Health 2014 (pp. 185-191). Bratislava: Comenius University.

24. ROCHON, W., S. FEINSTEIN and M. SOUKUP, 2006. Effectiveness of American Sign Language in Coaching Athletes who are Deaf. Retrieved from http://eric.ed.gov/?id=ED493867

25. SCHULTZ, J.L., L.J. LIEBERMAN, M.K. ELLIS and L.C. HILGENBRINCK, 2013 Ensuring the Success of Deaf Students in Inclusive Physical Education. Journal of Physical Education, Recreation et Dance, 84, 51-56.

26. STEWART, D.A. (1991). Deaf sport: The impact of sports within the Deaf community. Washington, DC: Gallaudet University Press.

27. STEWART, D.A. and T.N. KLUWIN, 2001. Teaching Deaf and hard of hearing students. Content, strategies and curriculum. Needham Heigst, MA: Allyn and Bacon.

28. STEWART, D.A., D. McCARTHY and J.A. ROBINSON, 1988. Participation in Deaf sport: Characteristics of Deaf sport directors. Adapted Physical Activity Quarterly. 5, 233244.

29. STEWART, D.A., J.A. ROBINSON and D. MCCARTHY, 1991. Participation in Deaf sport: Characteristics of elite Deaf athletes. Adapted Physical Activity Quarterly, 8, 136145.

30. SCHEETZ, N.A., 2004. Psychological aspects of deafness. Boston, MA: Pearson. ISBN $\underline{0205343473 .}$

31. SIMS, D.G., G.G. WALTER and R.C. WHITEHEAD, 1982. Deafness and communication. Baltimore, MD: Waverly Press.

32. STEWART D.A. and D.K. AMMONS, 2001. Future directions of the Deaflympics. Palaestra, 17, 45-49.

33. STEWART, D.A. and M.K. ELLIS, 1999. Physical education for deaf students. American Annals of the Deaf, 144, 315-319. 
34. STRNADOVÁ, V., 2001. Hádej, co řikám, aneb odezírání je nejisté umění [Guess what I am saying or lip-reading is an uncertain discipline] (2nd rev. edn.). ( $2^{\text {nd }}$ rev. ed.). Praha: ASNEP. ISBN 80-903035-0-1.

35. REICH, L.M. and B. LAVAY, 2009. Physical education and sport adaptations for students who are hard of hearing. Journal of Physical Education, Recreation et Dance, 80, 38-42, 49.

36. ZACCAGNINI, K.J., 2005. How physical education teacher education majors should be prepared to teach students with hearing loss: A national needs assessment. American Annals of the Deaf, 150, 273-282. 